\title{
Evaluation of root yield performance of newly bred orange-fleshed sweet potato genotypes in Ethiopia
}

\author{
Fekadu Gurmu* • Shiferaw Mekonen
}

\author{
South Agricultural Research Institute, Hawassa Research Centre, P.O. Box 6, Hawassa, Ethiopia.
}

*Corresponding author. E-mail: fekadugb@gmail.com. Tel: +251911743625.

Accepted $14^{\text {th }}$ December, 2018.

\begin{abstract}
Orange-fleshed sweet potato (OFSP) is rich in $\beta$-carotene and it is the cheapest staple food, easily accessible and year-round source of vitamin A. However, in Ethiopia, the acceptance of the OFSP varieties by farmers was low due to their low root dry matter content (RDMC). Therefore, a crossing block was established in 2013 to cross selected OFSP varieties with white-fleshed varieties in order to improve the RDMC of the OFSP varieties and thereby increase the adoption of the varieties. Nursery and preliminary yield trials were conducted in 2014 and 2015, and finally, national variety trials were conducted at four locations for two years (2016 and 2017) using 12 selected genotypes. The analysis of variance revealed that there was significant difference $(p<0.01)$ among the varieties for total root yield and RDMC. Two genotypes, Ukr/Eju-10 and Ukr/Eju-13 have been identified as best candidates for release based on their fresh root yield of 28.7 and $26.8 \mathrm{t}$ ha-1, RDMC of 31.9 and $31.4 \%$, resistance to sweet potato virus disease with low score of 1.4 and 1.6, respectively. The flesh colour of the two varieties is deep orange with high $\beta$-carotene contents of 12.48 and

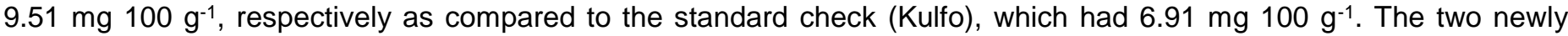
bred candidate varieties were ranked 1st and 2nd based on farmers' preference taste-test. Therefore, the two candidate varieties can be the potential OFSP varieties that can replace Kulfo, which is currently under production in Ethiopia.
\end{abstract}

Keywords: $\beta$-carotene, candidate varieties, dry matter, root yield, farmers preference test.

\section{INTRODUCTION}

Sweet potato (Ipomoea batatas L. Lam) is among very valuable root crops in Ethiopia and it is widely grown in the eastern, southern and south western parts of the country (Belehu, 2003, Tofu et al., 2007, Gurmu et al., 2015a). The roots are used as a staple food while the vines and leaves are used as animal feed. The orangefleshed sweet potato (OFSP) varieties are rich in $\beta$ carotene (pro-vitamin $A$ ). These varieties are playing a crucial role in preventing vitamin A deficiency in Africa which otherwise leads to blindness and maternal and preschool children mortality in many of the developing countries (WHO, 2009; Wang et al., 2011; Gurmu et al., 2015b).

The orange-fleshed sweet potato (OFSP) varieties are the cheapest staple food, easily accessible and yearround sources of vitamin A (Hagenimana et al., 2001; Mwanga et al., 2003; Kapinga et al., 2005; Burri, 2011; Gurmu et al., 2015a; Gurmu et al., 2012). Most of the orange-fleshed sweet potato varieties contain 3000 to $16000 \mu \mathrm{g} 100 \mathrm{~g}^{-1}$ of $\beta$-carotene and this contributes to 250 to $1300 \mu \mathrm{g} 100 \mathrm{~g}^{-1}$ retinol activity equivalents (RAE) (Kapinga et al., 2010). Therefore, according to Kapinga et al. (2005), addition of $100 \mathrm{~g}$ OFSP in a daily diet can prevent VAD in children and significantly reduce the death of mothers. Christina (2007) also indicated that, a $100 \mathrm{~g}$ OFSP can provide more than $6500 \mu \mathrm{g} \beta$-carotene, which is equivalent to more than $1000 \mu \mathrm{g}$ RAE. Therefore, $100 \mathrm{~g}$ of OFSP day- 1 exceeds the RDA to 
Table 1. Description of the experimental sites.

\begin{tabular}{|c|c|c|c|c|c|c|c|}
\hline \multirow{2}{*}{ Location } & \multirow{2}{*}{ Code } & \multirow{2}{*}{ Altitude (masl) ${ }^{\star}$} & \multirow{2}{*}{ Coordinates } & \multirow{2}{*}{ Annual rainfall $(\mathrm{mm})$} & \multicolumn{2}{|c|}{ Mean annual temperature $\left({ }^{\circ} \mathrm{C}\right)$} & \multirow{2}{*}{$\mathbf{R H}(\%)$} \\
\hline & & & & & Min & Max & \\
\hline Dilla & DIL & 1519 & $06^{\circ} 22^{\prime} 49^{\prime \prime} \mathrm{N}, 38^{\circ} 18^{\prime} 25^{\prime \prime} \mathrm{E}$ & 1354.6 & 12.9 & 28.1 & 65.0 \\
\hline Halaba & HAL & 1772 & $07^{\circ} 18^{\prime} 38^{\prime \prime} \mathrm{N}, 38^{\circ} 05^{\prime} 38^{\prime \prime} \mathrm{E}$ & 928.8 & 14.6 & 28.6 & 58.3 \\
\hline Hawassa & HAW & 1700 & $07^{\circ} 03^{\prime} 54^{\prime \prime} \mathrm{N}, 38^{\circ} 28^{\prime} 59^{\prime \prime} \mathrm{E}$ & 1046.3 & 13.3 & 27.6 & 62.1 \\
\hline Werer & WER & 750 & $09^{\circ} 16^{\prime} 55^{\prime \prime} \mathrm{N}, 40^{\circ} 09^{\prime} 23^{\prime \prime} \mathrm{E}$ & 590.0 & 26.7 & 40.8 & - \\
\hline
\end{tabular}

${ }^{*}$ masl $=$ meter above sea level, $\mathrm{RH}=$ relative humidity. Source: National Meteorological Agency, Hawassa Main Branch.

Table 2. Description of sweet potato genotypes used for the study.

\begin{tabular}{clll}
\hline No. & Genotypes & Short names & Origin \\
\hline 1 & Ukrewe $\times$ Ejumula-10 & Ukr/Eju-10 & Ethiopia \\
2 & Ukrewe $\times$ Ejumula-13 & Ukr/Eju-13 & Ethiopia \\
3 & Resisto $\times$ Temesgen-14 & Res/Tem-14 & Ethiopia \\
4 & Resisto $\times$ Temesgen-23 & Res/Tem-23 & Ethiopia \\
5 & Jewel & Jewel & CIP-Kenya \\
6 & Carrot Dar & Carrot Dar & CIP-Kenya \\
7 & Resisto $\times$ PIPI-21 & Res/Pip-21 & Ethiopia \\
8 & SPK004/6/6 & SPK004/6/6 & Uganda \\
9 & Maputha -1 & Maputha -1 & CIP-Kenya \\
10 & SPK004/6 & SPK004/6 & Uganda \\
11 & Tainung-15 & Tainung-15 & CIP-Kenya \\
12 & Kulfo & Kulfo & Ethiopia \\
\hline
\end{tabular}

prevent VAD. As a result, depending upon the colour intensity of the OFSP variety used, and taking into account losses of $\beta$-carotene during cooking, which accounts for an approximately $20 \%$ loss through boiling (Van Jaarsveld et al., 2006), a quarter of a cup to one cup of boiled and mashed sweet potato meets the RDA of vitamin A of a young child (Hagenimana et al., 2001; Fleshman et al., 2011; Gurmu et al., 2015a). OFSP is also a good source of energy, which is equivalent to 293$460 \mathrm{~kJ} 100 \mathrm{~g}^{-1}$ (Woolfe, 1992; Hagenimana et al., 2001).

However, in Ethiopia, the white fleshed sweet potato varieties are commonly grown by farmers and farmers prefer them due to their high root dry matter content as compared to the OFSP varieties. Therefore, improving the dry matter contents of the OFSP and evaluating their performance with farmers' participation is very vital to increase their acceptance by farmers. With this rationale, the current study was conducted to evaluate the newly bred OFSP varieties for root yield, root dry matter and $\beta$ carotene contents and to identify the best and farmer preferred candidate varieties for release.

\section{MATERIALS AND METHODS}

\section{Study areas}

A crossing block was established at the South
Agricultural Research Institute in Hawassa city, Ethiopia. Hawassa is located at $7^{\circ} 03^{\prime} 54^{\prime \prime} \mathrm{N}$ and $38^{\circ} 28^{\prime} 59^{\prime \prime} \mathrm{E}$ with an altitude of 1750 meter above sea level. It is found at $275 \mathrm{~km}$ south of the Ethiopian capital, Addis Ababa. The field evaluation was conducted for two years (2016-2017) at four locations (Dilla, Halaba and Hawassa in the Southern Nation, Nationalities and peoples' Regional State and Werer in Afar Regional State in Ethiopia. The details of test sites are summarized in Table 1.

\section{Plant materials}

Twelve orange-fleshed sweet potato genotypes that were selected from diallel cross families were evaluated along with one released OFSP check variety (Kulfo). The list of the genotypes is presented in Table 2 . The genotypes were selected based on their high root dry matter content (RDMC), orange flesh colour ( $\beta$-carotene content) and fresh root yield.

\section{Experimental design and field layout}

The national variety trial was conducted using a randomized complete block design with three replications. The experimental plots consisted of a four row plot of three meters long for each genotype. The 
spacing between each row and plants was 0.60 and 0.30 $\mathrm{m}$, respectively which resulted in a total of 10 plants per row and 40 plants per plot (Belehu, 2003; ARC, 2015). The experiments were planted in July to August and harvested in November to December, both in 2016 and 2017. The two central rows were used for data recording and harvesting. The experiment was conducted under rainfed conditions. No fertilizers were applied at any of the test sites and weeding and cultivation were done as recommended for the crop in Ethiopia (ARC, 2015).

\section{Data collection}

Fresh root yield was the major traits followed by root dry matter and $\beta$-carotene contents. All the data samples were taken from each replicate at each location. Fresh root yield $\left(\mathrm{t} \mathrm{ha}^{-1}\right)$ was measured from two central rows and expressed as harvested fresh root weight in $\mathrm{kg} \mathrm{plot}^{-1}$ and later converted to tonnes per hectare. RDMC estimated as a percentage of root dry weight $(\mathrm{g})$ to fresh root weight $(\mathrm{g})$ where 100 to $200 \mathrm{~g}$ samples were taken from roots of sampled plants in the plot and the samples were dried in an oven at $80^{\circ} \mathrm{C}$ for 48 hours. $\beta$-carotene content was analysed at the International Potato Center (CIP) in Uganda using Near Infrared Reflectance

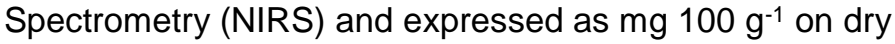
weight basis. Farmers' preference tested was conducted using the following criteria: root flesh colour, sugariness of the boiled root, test, powderiness, texture and overall acceptance of the boiled roots. More than 40 farmers had participated on the evaluation of the genotypes. The panelist farmers were given cards of different colours: green for best, yellow for medium and red for bad and they ranked the genotypes based on the above criteria.

\section{Data analysis}

\section{Analysis of variance}

A combined analysis of fresh root yield, RDMC and $\beta$ carotene content data across the environments were analysed using GenStat 14th edition (Payne et al. 2011) and SAS version 9.3(SAS Institute Inc. 2003) statistical packages. The following statistical model was used for combined analysis of variance over environments:

$Y_{i j k l}=\mu+G_{i}+L_{j}+Y_{k}+G L_{i j}+G Y_{i k}+L Y_{j k}+G L Y_{i j k}+B_{l(j)}+\varepsilon_{i j k l}$

Where: $Y_{\mathrm{ijk}}$ is observed value of genotype $i$ in block / and of location $j$ and year $k, \mu$ is grand mean, Gis effect of genotype $i, \mathrm{~L}_{\mathrm{j}}$ is location effect, $\mathrm{Y}_{\mathrm{k}}$ is year effect, $\mathrm{GL} \mathrm{Y}_{\mathrm{ijk}}$ is the interaction effect of genotype $i$ with location $j$ and year $k, \mathrm{~B}_{(j)}$ is the effect of block $/$ in location $j$, $\epsilon_{\mathrm{ij} k \mathrm{jl}}$ is error (residual) effect of genotype $i$ in block / of location $j$ and year $k$.

\section{$G \times E$ and stability analysis}

$G \times E$ and stability analyses were conducted using a GGEbi-plot procedure (Yan 2001; Yan 2002; Yan et al. 2007) in GenStat 14th edition.

The model for a GGE bi-plot (Yan, 2002; Yan et al., 2007) based on singular value decomposition (SVD) of $t$ principal components is:

$$
\bar{Y}_{i j}-\mu_{i}-\beta_{j}=\sum_{k=1}^{t} \lambda_{k} \alpha_{i k} \gamma_{j k}+\varepsilon_{i j}
$$

Where: $\bar{Y}_{i j}$ is the performance of genotype $i$ in environment $j, \mu$ is the grand mean, $\beta_{j}$ is the main effect of environment $j, k$ is the number of principal components (PC); $\lambda_{k}$ is singular value of the $k^{\text {th }} \mathrm{PC}$; and $\alpha_{i k}$ and $\gamma_{j k}$ are the scores of $i^{\text {th }}$ genotype and $j^{\text {th }}$ environment, respectively for $\mathrm{PC}_{\mathrm{k}} ; \varepsilon_{i j}$ is the residual associated with genotype $i$ in environment $j$.

\section{RESULTS AND DISCUSSION}

\section{Mean performance of the genotypes for fresh root yield}

The combined analysis of variance showed that there was a highly significant $(p<0.001)$ difference among the four test environments and among the 12 sweet potato genotypes for fresh root yield (Table 3 ). The result also showed that genotype $\times$ environment interaction (GEI) was highly significant $(p<0.001)$ for this trait. The treatments effects had accounted for the large portion of the total sum of squares, which was $26.0 \%$, followed by error $(25.5 \%)$ and locations $(19.0 \%)$. Year effect accounted only for a very small portion of the total sum of squares $(0.4 \%)$. The three way interaction effects (treatment $\times$ location $\times$ year) accounted for $8.0 \%$. Although the higher portion of the total sum of squares was accounted for by the genotypic effects, which better explained the inherent differences between the genotypes, however, the analysis showed the presence of significant GxE interaction effects and the presence of significant $G \times E$ interaction effect hinders variety recommendation since it reduces wider adaptability and stability of varieties to different growing conditions across locations (Annicchiarico, 2002). This necessitated stability analysis.

The mean fresh root yield of the genotypes over two years at the four locations is presented in Table 4. The genotypes responded differently to the different locations over the two years. Since the locations are different in terms of altitude, soil types, rainfall amount, temperature, humidity etc, the genotypes responded to these variations differently due to their difference in their 
Table 3. Analysis of variance for root yeild of sweet potato genotypes evaluated across eight environments.

\begin{tabular}{lcccc}
\hline Source of variation & $\mathbf{d f}$ & Sum of squares (SS) & Mean squares (MS) & $\%$ SS \\
\hline Treatment (Trt) & 11 & 7928.2 & $720.8^{* *}$ & 26.0 \\
Block (B) & 2 & 23.6 & $11.8 \mathrm{~ns}$ & 0.1 \\
Location (Loc) & 3 & 5813.2 & $1937.7^{\star * *}$ & 19.0 \\
Year & 1 & 132.0 & $132.0^{\star}$ & 0.4 \\
Trt $\times$ Loc & 33 & 3087.8 & $93.6^{*}$ & 10.1 \\
Trt $\times$ Year & 11 & 1447.5 & $131.6^{*}$ & 4.7 \\
Loc $\times$ Year & 3 & 1890.2 & $630.1^{* *}$ & 6.2 \\
Trt $\times$ Loc $\times$ Year & 33 & 2427.9 & $73.6^{*}$ & 8.0 \\
Error & 190 & 7769.7 & 40.9 & 25.5 \\
Total & 287 & & & \\
\hline
\end{tabular}

Table 4. Total storage root yield performance of sweet potato clones tested across locations and over years (ton/ha).

\begin{tabular}{|c|c|c|c|c|c|c|c|c|c|c|c|c|}
\hline \multirow[b]{2}{*}{ Genotype } & \multicolumn{5}{|c|}{2016} & \multicolumn{4}{|c|}{2017} & \multirow[b]{2}{*}{ Mean } & \multirow[b]{2}{*}{ Overall mean } & \multirow[b]{2}{*}{$\begin{array}{c}\text { Yield advantage } \\
\text { over standard check } \\
(\%)\end{array}$} \\
\hline & $\stackrel{\text { Ф }}{\overline{\bar{D}}}$ & $\frac{\pi}{\frac{\pi}{\pi}}$ & $\begin{array}{l}\mathbb{8} \\
\mathscr{X} \\
\mathbb{8} \\
3 \\
\mathbb{1}\end{array}$ & $\frac{\bar{d}}{\frac{1}{亠}}$ & $\begin{array}{l}\frac{c}{\mathbb{J}} \\
\stackrel{\mathbb{N}}{\Sigma}\end{array}$ & 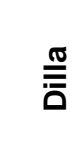 & $\frac{\pi}{\frac{0}{10}}$ & 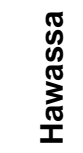 & $\frac{\bar{d}}{\frac{1}{d}}$ & & & \\
\hline Ukr/Eju-10 & 31.8 & 17.7 & 25.1 & 37.1 & 27.9 & 27.6 & 17.1 & 27.8 & 45.5 & 29.5 & 28.7 & 168.9 \\
\hline Ukr/Eju-13 & 30.3 & 22.7 & 25.8 & 27.4 & 26.6 & 24.8 & 16.5 & 27.9 & 38.8 & 27.0 & 26.8 & 150.9 \\
\hline Res/Tem-14 & 31.0 & 13.5 & 22.5 & 29.5 & 24.1 & 20.3 & 10.5 & 13.9 & 23.6 & 17.1 & 20.6 & 92.8 \\
\hline Res/Tem-23 & 9.3 & 13.4 & 18.2 & 7.1 & 12.0 & 13.2 & 6.5 & 7.6 & 10.3 & 9.4 & 10.7 & 0.2 \\
\hline Jewel & 20.1 & 17.9 & 13.9 & 27.1 & 19.8 & 25.2 & 6.8 & 21.5 & 27.4 & 20.2 & 20.0 & 87.1 \\
\hline Carrot Dar & 27.1 & 17.7 & 14.8 & 28.3 & 22.0 & 17.5 & 6.3 & 22.4 & 22.7 & 17.2 & 19.6 & 83.5 \\
\hline Res/Pip-21 & 32.2 & 24.2 & 19.1 & 16.3 & 23.0 & 21.2 & 12.7 & 17.3 & 38.9 & 22.5 & 22.7 & 113.1 \\
\hline SPK004/6/6 & 31.4 & 15.1 & 20.5 & 10.2 & 19.3 & 21.6 & 12.3 & 20.7 & 31.6 & 21.6 & 20.4 & 91.4 \\
\hline Maputha-1 & 21.5 & 9.0 & 13.4 & 6.6 & 12.6 & 23.4 & 11.4 & 23.3 & 21.8 & 20.0 & 16.3 & 52.7 \\
\hline SPK 004/6 & 26.4 & 7.4 & 5.4 & 11.5 & 12.7 & 19.1 & 14.2 & 15.3 & 31.9 & 20.1 & 16.4 & 53.4 \\
\hline Tainung-15 & 20.0 & 5.6 & 5.4 & 26.6 & 14.4 & 19.5 & 11.7 & 15.7 & 32.2 & 19.8 & 17.1 & 60.0 \\
\hline Mean & 24.8 & 13.9 & 16.1 & 19.1 & 18.5 & 21.0 & 11.4 & 18.7 & 28.3 & 19.8 & 19.2 & \\
\hline LSD (5\%) & 8.7 & 8.6 & 10.7 & 12.2 & 5.3 & 7.1 & 6.6 & 8.7 & 11.3 & 5.8 & 10.3 & \\
\hline CV & 20.6 & 33.5 & 34.3 & 35.8 & 33.5 & 25.2 & 29.4 & 31.5 & 33.2 & 30.1 & 33.4 & \\
\hline
\end{tabular}


Table 5. Mean dry matter and beta-carotene contents of sweet potato clones evaluated over years.

\begin{tabular}{|c|c|c|c|c|c|}
\hline \multirow{2}{*}{ S. no. } & \multirow{2}{*}{ Genotypes } & \multicolumn{3}{|c|}{ Dry matter content (\%) } & \multirow{2}{*}{$\begin{array}{c}\text { Beta-carotene content (mg } \\
\left.100 \mathrm{~g}^{-1}\right)(2016)\end{array}$} \\
\hline & & 2016 & 2017 & Mean & \\
\hline 1 & Ukr/Eju-10 & 32.1 & 31.8 & 31.9 & 12.4 \\
\hline 2 & Ukr/Eju-13 & 31.3 & 31.6 & 31.4 & 9.5 \\
\hline 3 & Res/Tem-14 & 31.8 & 31.3 & 31.5 & 8.5 \\
\hline 4 & Res/Tem-23 & 25.3 & 24.2 & 24.8 & 7.3 \\
\hline 5 & Jewel & 28.2 & 30.4 & 29.3 & 11.3 \\
\hline 6 & Carrot Dar & 28.6 & 31.8 & 30.2 & 10.5 \\
\hline 7 & Res/Pip-21 & 29.0 & 31.6 & 30.3 & 2.4 \\
\hline 8 & SPK004/6/6 & 30.2 & 30.3 & 30.2 & 8.5 \\
\hline 9 & Maputha $^{-1}$ & 28.5 & 27.8 & 28.2 & 8.8 \\
\hline 10 & SPK 004/6 & 28.6 & 29.6 & 29.1 & 9.6 \\
\hline 11 & Tainung-15 & 28.6 & 27.6 & 28.1 & 10.3 \\
\hline 12 & Kulfo & 23.3 & 22.5 & 22.9 & 8.3 \\
\hline \multicolumn{2}{|c|}{ Mean } & 28.7 & 29.2 & 29.0 & 9.0 \\
\hline \multicolumn{2}{|c|}{ LSD (5\%) } & 2.1 & 2.4 & 2.2 & 2.5 \\
\hline \multicolumn{2}{|c|}{ CV } & 10.2 & 8.3 & 8.5 & 6.3 \\
\hline
\end{tabular}

genetic makeup. Dilla was the best environment for fresh root yield during 2016 with a mean yield of $24.8 \mathrm{t} \mathrm{ha}^{-1}$ while in 2017 Werer was the best with a mean of $28.3 \mathrm{t}$ ha $^{-1}$. Halaba was the least yielding environment during both years. Genotypes Eju/Ukr-10 and Eju/Ukr-13 were the highest yielding genotypes across the locations and years with a mean of 28.7 and $26.8 \mathrm{t} \mathrm{ha}^{-1}$, respectively. The two genotypes showed a yield advantage of 168.9 and $150.9 \%$, respectively over the standard check (Kulfo). Res/Tem-23 and Kulfo both gave the lowest yield with a mean of $10.7 \mathrm{t} \mathrm{ha}^{-1}$.

The presence of a highly significant difference $(p<$ 0.01 ) between the four test locations and the two years indicates that the genotypes performed differently across locations and over years. The significant genotype by environment interaction also indicates the significance of environmental effects, locations and years in evaluating sweet potato genotypes for fresh root yield. Similar findings were reported by various authors, who indicated that sweet potato genotypes are sensitive to environmental variations (Wolfgang et al., 2005; Mbwaga et al., 2008; Chiona, 2009; Osiru et al., 2009; Moussa et al., 2011).

\section{Mean performance of the genotypes for root dry matter and $\beta$-carotene contents}

The mean root dry matter and $\beta$-carotene content of the genotypes is presented in Table 5 . The mean root dry matter content of the genotypes ranged from 22.9 to $31.9 \%$. The highest mean root dry matter content was recorded for three genotypes: Eju/Ukr-10, Eju/Ukr-13 and Res/Tem-14 with a mean of $31.9,31.4$ and $31.5 \%$, respectively. The lowest mean root dry matter content
$(22.9 \%)$ was recorded for the check variety, Kulfo. Most African farmers prefer varieties with high RDMC (>30\%) since this trait has direct effect on the taste of sweet potato varieties (Belehu, 2003; Kapinga and Carey, 2003; Ssebuliba et al., 2006, Tofu et al., 2007). Varieties with low RDMC are watery, have poor taste and not preferred by African farmers.

The $\beta$-carotene content of the genotypes ranged from

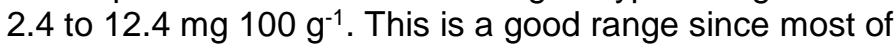
the orange fleshed sweet potato varieties contain 3 to 16 $\mathrm{mg} 100 \mathrm{~g}^{-1}$ of $\beta$-carotene (Kapinga et al., 2010). Four genotypes showed a mean $\beta$-carotene content that is greater than $10 \mathrm{mg} 100 \mathrm{~g}^{-1}$. The highest $\beta$-carotene content (12.4 mg $100 \mathrm{~g}^{-1}$ ) was recorded for a genotype Ukr/Eju-10 (Table 5). The flesh colour of the genotypes, which is an indication of the amount of $\beta$-carotene content in the roots, ranged from pale orange to deep orange. The higher the intensity of the orange colour, the higher will be the $\beta$-carotene content (Mcharo and LaBonte, 2007; Burgos et al., 2009; Vimala and Hariprakash, 2011).

\section{Stability analysis}

Figure 1 displays the GGE-biplot analysis of fresh root yield. The genotypes 1 (Ukr/Eju-10) and 2 (Ukr/Eju-13) had relatively higher PC1 values indicating that these genotypes had high average fresh root yield. On the other hand, the genotypes 4 (Res/Tem-23) and 12 (Kulfo) had the lowest PC1 values which indicates that they had low fresh root yields. Among the test genotypes, only four of them showed a fresh root yield that was below average (Figure 1). Among the test environments, Werer had relatively higher PC1 score showing that this environment was high yielding environment during both years as compared to the other environments (Figure 1). 


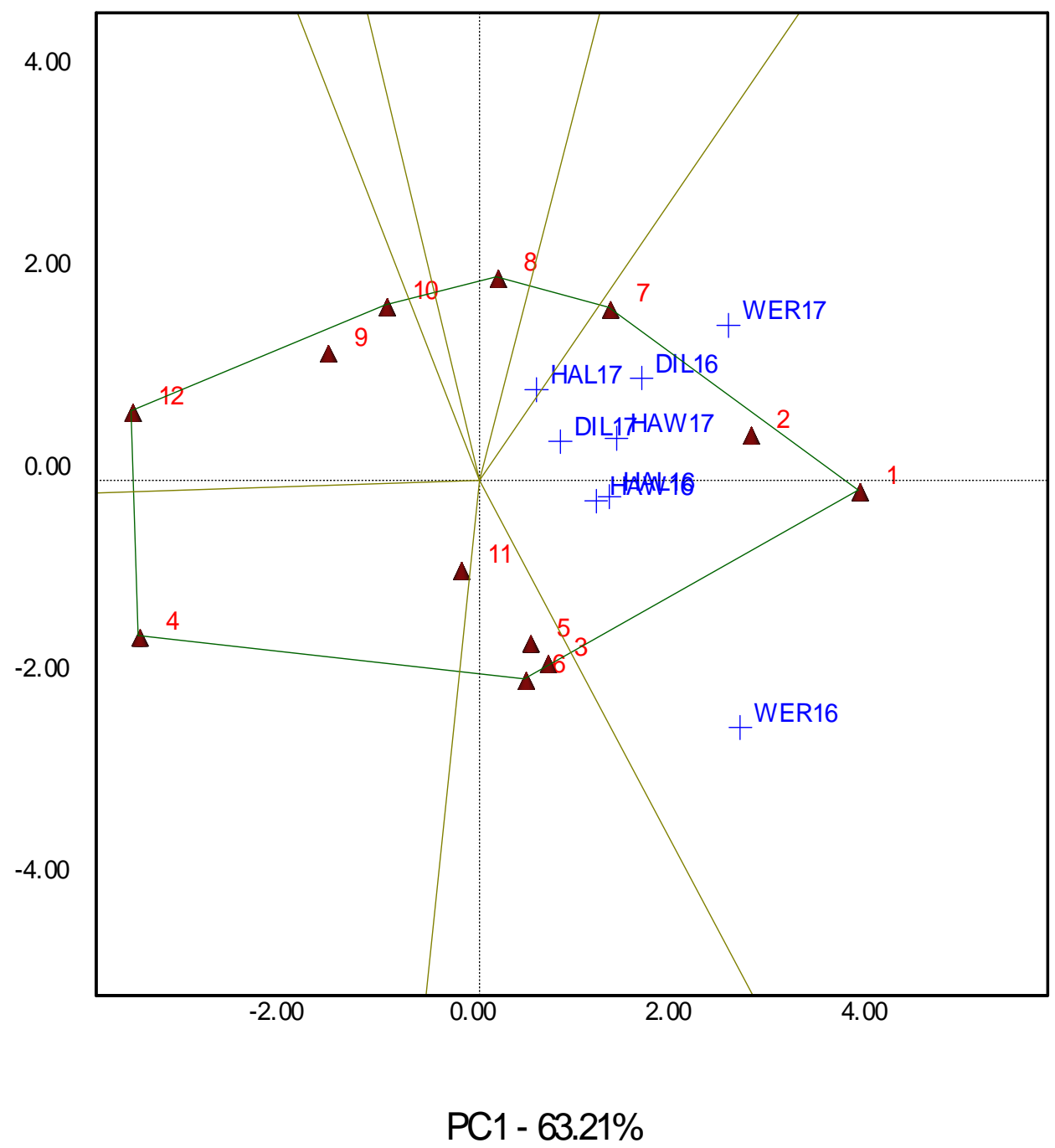

Figure 1. GGE-biplot showing eight environments (four locations $x$ two years) and 12 orange-fleshed sweet potato genotypes evaluated for fresh root yield. DIL 16= Dilla 2016; DIL 17 = Dilla 2017; HAL $16=$ Halaba 2016; HAL 17 = Halaba 2017; HAW 16 = Hawassa 2016; HAW 17 = Hawassa 2017; WER $16=$ Werer 2016; WER 17 = Werer 2017.

The stability of the genotypes across the test environments is displayed in Figure 2. Genotypes 1 (Ukr/Eju-10) and 2 (Ukr/Eju-13) had shorter absolute length of projection on the $\mathrm{Y}$-axis showing that they were stable genotypes. On the other hand, genotypes with longer absolute length of projection on the $\mathrm{Y}$-axis such as 8 (spk004/6/6), 7(Res/Pip-21), 10 (spk004/6), 6 (Carrot Dar), 3 (Res/Tem-14) and 5 (Jewel) were less stable genotypes.

According to Yan (2001) large positive PC1 scores for genotypes indicate that those genotypes had relatively higher mean values. The average environment coordinate (AEC) is the line that passes through the biplot origin and separates genotypes with mean values below average and above average (Yan et al., 2000; Yan, 2001). Those genotypes to the right of this line are high yielders, while those to the left are low yielders (Yan,
2001; Yan and Kang, 2003; Gurmu et al., 2012). Therefore, eight genotypes had high fresh root yields that were above average and two of them (Ukr/Eju-10 and Ukr/Eju-13) were best yielders.

According to Yan (2001), genotypes with PC2 scores near zero are the most stable genotypes. Accordingly, two genotypes, Ukr/Eju-10 and Ukr/Eju-13, which had PC2 scores near zero were found the most stable genotypes among the tested genotypes. These genotypes also had the highest mean fresh root yields.

\section{Farmers' preference test}

The mean farmers' preference for orange-fleshed sweet potato genotypes evaluated across locations is presented in Table 6. Accordingly, the genotypes (Ukr/Eju-10) and 


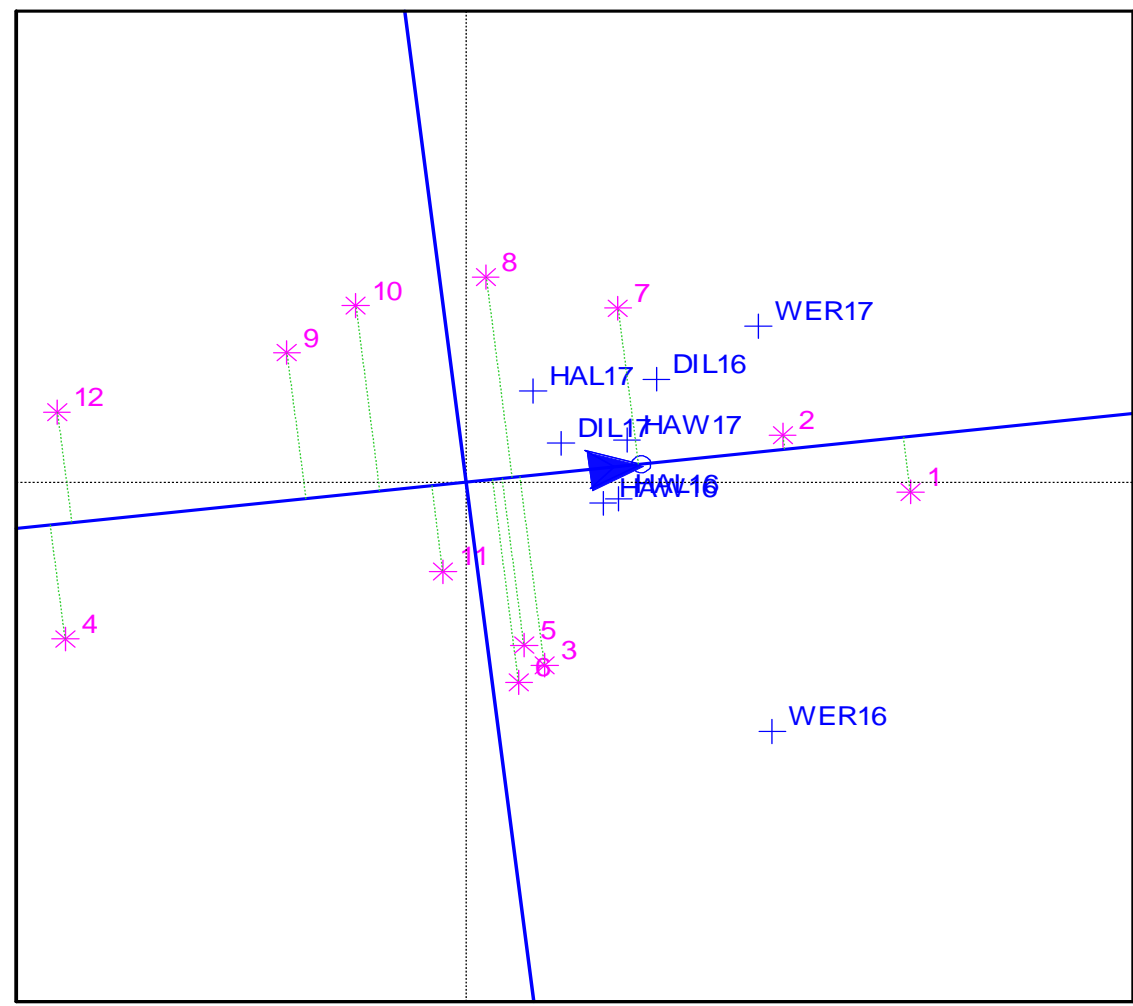

PC1 - 63.21\%

Figure 2. Mean performance of 12 orange-fleshed sweet potato genotypes and their stability across eight environments for fresh root yield. DIL 16 = Dilla 2016; DIL 17 = Dilla 2017; HAL 16 = Halaba 2016; HAL 17 = Halaba 2017; HAW 16 = Hawassa 2016; HAW 17 = Hawassa 2017; WER 16 = Werer 2016; WER $17=$ Werer 2017.

Table 6. Mean farmers' preference for sweet potato clones evaluated across locations.

\begin{tabular}{|c|c|c|c|c|c|c|c|c|c|}
\hline \multirow{2}{*}{$\begin{array}{l}\text { S. } \\
\text { no. }\end{array}$} & \multirow[b]{2}{*}{ Genotypes } & \multicolumn{6}{|c|}{ Parameters } & \multirow[b]{2}{*}{ Average } & \multirow[b]{2}{*}{ Rank } \\
\hline & & Color & Sugariness & Test & Powderiness & Texture & $\begin{array}{c}\text { Overall } \\
\text { acceptance }\end{array}$ & & \\
\hline 1 & Ukr/Eju-10 & 4.7 & 4.0 & 4.7 & 4.3 & 4.6 & 4.7 & 4.5 & 1 \\
\hline 2 & Ukr/Eju-13 & 3.1 & 3.4 & 3.1 & 3.4 & 3.3 & 3.4 & 3.3 & 2 \\
\hline 3 & Res/Tem-14 & 2.7 & 2.5 & 2.7 & 2.6 & 3.3 & 2.5 & 2.7 & 4 \\
\hline 4 & Res/Tem-23 & 1.9 & 1.9 & 1.7 & 1.9 & 2.3 & 1.8 & 1.9 & 10 \\
\hline 5 & Jewel & 1.6 & 1.9 & 1.8 & 1.6 & 2.2 & 1.9 & 1.8 & 11 \\
\hline 6 & Carrot Dar & 1.7 & 1.7 & 1.7 & 1.6 & 2.3 & 1.9 & 1.8 & 12 \\
\hline 7 & Res/Pip-21 & 2.5 & 2.7 & 2.6 & 2.8 & 2.7 & 2.7 & 2.7 & 5 \\
\hline 8 & SPK004/6/6 & 2.6 & 2.7 & 2.7 & 3.0 & 2.7 & 2.7 & 2.7 & 6 \\
\hline 9 & Maputha-1 & 2.5 & 2.3 & 2.8 & 2.6 & 2.2 & 2.7 & 2.5 & 7 \\
\hline 10 & SPK 004/6 & 2.3 & 2.2 & 2.6 & 2.5 & 2.2 & 2.5 & 2.4 & 9 \\
\hline 11 & Tainung-15 & 3.0 & 2.7 & 2.9 & 2.9 & 2.7 & 2.7 & 2.8 & 3 \\
\hline \multirow[t]{2}{*}{12} & Kulfo & 2.2 & 2.6 & 2.4 & 2.5 & 2.6 & 2.7 & 2.5 & 8 \\
\hline & Mean & 2.6 & 2.5 & 2.6 & 2.6 & 2.8 & 2.7 & 2.6 & \\
\hline
\end{tabular}

(Ukr/Eju-13) were ranked $1^{\text {st }}$ and $2^{\text {nd }}$ by the farmers. The OFSP variety (Kufo) that is currently under production in
Ethiopia and used as a check variety in this study was ranked $8^{\text {th }}$. The result demonstrated that the two 
candidate varieties met the famers' preference in terms of the above criteria which is very important criteria for the acceptability of OFSP varieties.

\section{CONCLUSION}

The root dry matter content of OFSP varieties greatly influences the acceptance and adoption of varieties by farmers. Among the 12 OFSP genotypes evaluated across four locations and over two years, two candidate genotypes were selected based on their better root yield, dry matter content and $\beta$-carotene content. These genotypes had wider adaptability and stability across environments. More importantly, the genotypes were also selected by farmers as best ones and ranked $1^{\text {st }}$ and $2^{\text {nd }}$ among the tested genotypes. Therefore, these genotypes will be presented for the national variety verification for release and registration. The genotypes are potential candidates that could replace Kulfo variety, an OFSP variety that is currently grown in Ethiopia.

\section{ACKNOWLEDGEMENTS}

The financial support of the South Agricultural Research Institute (SARI), the Ethiopian Institute of Agricultural Research (EIAR) and the International Potato Center (CIP) is highly acknowledged.

\section{REFERENCES}

Annicchiarico P (2002). Genotype x Environment Interactions. Challenges and Opportunities for Plant Breeding and Cultivar Recommendations. Food and Agriculture Organization, Rome, Italy.

ARC (2015). Sweet potato production and field management in Ethiopia, Production Manual. Awassa Agricultural Research Center, Hawassa, Ethiopia, 2015.

Belehu T (2003). Agronomical and Physiological Factors Affecting Growth, Development and Yield of Sweet potato in Ethiopia. PhD Thesis, University of Pretoria, Pretoria.

Burgos B, Carpio R, Sanchez C, Paola S, Eduardo P, Espinoza J, Grüneberg W (2009). A colour chart to screen for high $\beta$-carotene in OFSP breeding. The $15^{\text {th }}$ Triennial Symposium of the International Society for Tropical Root Crops (ISTRC), Lima. 2-6 November, 2009. ISTRC, Lima, Peru. pp. 47-52.

Burri BJ (2011). Evaluating Sweet potato as an intervention food to prevent vitamin A deficiency. Comprehensive Rev. Food Sci. Food Saf. 10:118-130.

Chiona M (2009). Towards Enhancement of $\beta$-carotene Content of High Dry Mass Sweet potato Genotypes in Zambia. PhD Thesis, University of KwaZulu-Natal, Pietermaritzburg.

Christina SL (2007). Nutrient and Sensory Quality of Orange Fleshed Sweet potato. MSc Thesis, University of Pretoria, Pretoria.

Gurmu F, Lire E, Asfaw A, Alemayehu F, Rezene Y, Ambachew D (2012). GGE-biplot analysis of grain yield of faba bean genotypes in southern Ethiopia. Electron. J. Plant Breed. 3(3):898-907.

Gurmu F, Hussein S, Laing M (2015a). The potential of orangefleshed Sweet potato to prevent vitamin A deficiency in Africa. Int. J. Vitam. Nutr. Res. 84(1-2):65-78.

Gurmu F, Hussein S, Laing M (2015b). Diagnostic assessment of Sweet potato production in Ethiopia : constraints, post-harvest handling and farmers' preferences. Res. Crops. 16(1):104-115.
Hagenimana V, Low J, Anyango M, Kurz K, Gichuki ST, Kabira J (2001). Enhancing vitamin A intake in young children in Western Kenya: orangefleshed Sweet potatoes and women farmers can serve as key entry points. Food Nutr. Bullet. 22:370-387.

Kapinga RE, Carey EE (2003). Present status of Sweet potato breeding for eastern and southern Africa. In: Rees, D., Oirschot, Q.\& Kapinga, R., editors. Sweet potato Post-harvest Assessment: Experiences from East Africa. Natural Resources Institute, Chatham, UK.

Kapinga R, Anderson P, Crissman C, Zhang D, Lemaga B, Opio F (2005). Vitamin A partnership for Africa: a food based approach to combat vitamin A deficiency in sub-Saharan Africa through increased utilization of orange fleshed Sweet potato. Chronica Hortic. 45(3):1214

Kapinga R, Tumwegamire S, Ndunguru J, Andrade MI, Agili S, Mwanga ROM, Laurie S, Dapaah H (2010). Catalogue of Orange Fleshed Sweet potato Varieties for Sub-Saharan Africa. International Potato Center (CIP), Lima, Peru.

Mbwaga Z, Mataa M, Msabaha M (2008). Quality and yield of orange fleshed Sweet potato (Ipomoea batatas) varieties grown in different agro-ecologies. In: Kasem, Z.A., editors. The $8^{\text {th }}$ African Crop Science Society (ACSS) Conference Proceeding, El-Minia, Egypt. 27-31 October, 2007. African Crop Sci. Soc. pp. 339-345.

Mcharo M, LaBonte D (2007). Genotypic variation among Sweet potato clones for $\beta$-carotene and sugar content. Proceedings of the 13th International Society for Tropical Root Crops (ISTRC) Symposium, Arusha, Tanzania. 9-15 November, 2003. ISTRC. pp. 746-754.

Moussa SAM, Hala AAE, Nashwa IAE (2011). Stability study of Sweet potato yield and its component characters under different environments by joint regression analysis. J. Hortic. Science and Ornamental Plants. 3:43-54.

Mwanga ROM, Odongo B, Niringiye C, Zhang D, Yencho GC, Kapinga R (2003). Orange fleshed Sweet potato breeding activities in Uganda. In: The $6^{\text {th }}$ Conference of the African Crop Science Society (ACSS) Conference Proceeding, 12-17 October, 2003, Nairobi. African Crop Science Society, Kampala, Uganda.

Osiru MO, Olanya OM, Adipala E, Kapinga R, Lemaga B (2009). Yield stability analysis of Ipomoea batatas L. cultivars in diverse environments. Austr. J. Crop Sci. 3:213-220.

Payne RW, Murray DA, Harding SA, Baird DB, Soutar DM (2011). GenStat for Windows (14th Edition) Introduction. VSN International, Hemel Hempstead, UK.

SAS Institute Inc., (2003). Version 9.1. SAS Institute Inc., Cary, NC.

Ssebuliba JM, Muyonga JH, Ekere W (2006). Performance and acceptability of orange fleshed Sweet potato cultivars in eastern Uganda. Afr. Crop Sci. J. 14:231-240.

Tofu A, Anshebo T, Tsegaye E, Tadesse T (2007). Summary of progress on orange-fleshed Sweet potato research and development in Ethiopia. In: Proceedings of the 13th International Society for Tropical Root Crops (ISTRC) Symposium, Arusha, 9-15 November, 2003. ISTRC, Arusha, Tanzania.

Van Jaarsveld PJ, De Wet M, Harmse E, Nestel P, RodriguezAmaya DB (2006). Retention of $\beta$-carotene in boiled, mashed orange-fleshed Sweet potato. J. Food Compos. Anal. 19(4):321-329.

Vimala B, Hariprakash B (2011). Variability of morphological characters and dry matter content in the hybrid progenies of Sweet potato [Ipomoea batatas (L.) Lam.]. Geneconserve 10:65-86.

Wolfgang JG, Manrique K, Zhang D, Hermann M (2005). Genotype x environment interactions for a diverse set of Sweet potato clones evaluated across varying ecogeographic conditions in Peru. Crop Sci. 45:2160-2171.

Woolfe JA (1992). Sweet potato: An Untapped Food Resource. Cambridge University Press, Cambridge, United Kingdom.

Yan W (2001). GGE Biplot: A Windows application for graphical analysis of multi-environment trial data and other types of two-way data. Agron J. 93:1111-1118.

Yan W (2002). Singular-value partitioning in biplot analysis of multienvironment trial data. Agron. J. 94:990-996.

Yan W, Cornelius PL, Crossa J, Huntt LA (2001). Two types of GGE biplots for analyzing multi-environment trial data. Crop Sci. 41:656663. 
Yan W, Kang MS (2003). GGE Biplot Analysis: A Graphical Tool for Breeders, Geneticists, and Agronomists. CRC Press, Boca Raton, Florida.

Yan W, Kang MS, Ma B, Woods S, Cornelius PL (2007). GGE Biplot vs. AMMI analysis of genotype-by-environment data. Crop Sci. 47:643-655. 